Paper Ref: 873

\title{
REGULATING EMPLOYMENT RELATIONS \\ THROUGH WORKPLACE LEARNING: \\ A STUDY OF SMALL EMPLOYERS
}

\begin{abstract}
Using data from two employer samples, the paper develops our understanding of small business employee skill formation and development processes in three main ways. First, it focuses on learning (what employees do) rather than on providing training (what employers do), as it is employee learning which influences individual and organisational performance. Second, it challenges the dominant focus on external training by presenting data on employer enablement of workplace employee learning and their motives for doing so. The diversity of workplace learning practices and their importance in smaller businesses are highlighted. Third, it situates workplace learning processes firmly within the context of the employment relationship, one in which employers and employees pursue distinctive interests in enabling/participating in learning.
\end{abstract}




\section{INTRODUCTION AND RESEARCH OBJECTIVES}

Skill deficiencies are argued to limit product and process innovation, productivity, and business growth and are cited as one of the key causes of Britain's poor productivity performance compared to other countries, notably the United States, Germany and France (HM Treasury 2002, 2004). Consequently, raising workforce skills has become a key public policy objective in Britain, with two white papers recently published (DfES 2003, 2005) and the Leitch review established to examine the UK's skill needs to 2020 (Leitch 2005).

Small employers, in particular, it is argued, provide insufficient workforce training (NTSF 2000a; HM Treasury 2002). Given the importance of small business in the UK economy - in 2004, businesses with fewer than 50 staff constituted 99\% of the UK's 4.3 million enterprises and employed $47 \%$ of the business sector workforce (www.sbs.gov.uk/statistics) - this alleged lack of training is contributing to the UK's continuing skills deficit and hampering national economic performance. Freel (2005) has noted an association between various skill indicators and training activity with innovativeness at the level of the individual small business.

This paper explores employee learning and training practices in small businesses. Specifically, it addresses three questions: how do employees learn in small business workplaces? What do they learn? Why do employees learn in the ways they do? To answer these questions requires that employee learning be situated in the context of 
the employment relationship and, in particular, to recognise employers' distinctive interests in providing or enabling learning opportunities for employees. In contrast with much prior research, the primary focus here is on workplace learning practices. The importance of external training for small business employers and employees is not denied; rather, the aim is to counter the over-emphasis by many researchers on 'formal' external training and the misconceptions surrounding small business learning processes that such over-emphasis generates. The following sections review the evidence base on workforce training in small businesses, discuss the methodology adopted for the present study, develop a conceptual framework to interpret the study findings, and conclude by summarising the main findings.

\section{EMPLOYEE LEARNING AND TRAINING IN SMALL BUSINESSES}

Many studies argue that small employers provide less workforce training than larger organisations (e.g. Westhead and Storey 1997; Westhead 1998; Cosh et al. 2003; Kitson and Wilkinson 2003; LSC 2005), seldom participate in government training initiatives (Curran et al. 1996; Kitching and Blackburn 2002; Matlay 2004) and are much less likely to become recognised for the Investors in People standard (Smith et al. 2002). By June 2005 just over 23,000 UK employers with fewer than 50 employees had become recognised for Investors in People, just $1.4 \%$ of businesses of this size; this contrasts with the $73 \%$ of organisations with 50 or more employees that have done so. ${ }^{1}$

Employee data can be used to suggest a similar picture. The National Adult 
Learning Survey found that those working in organisations employing fewer than 25 employees were less likely to report undertaking some form of learning activity during the previous three years than those working for larger employers (Fitzgerald et al. 2003). Using Labour Force Survey data, SFEDI (2004) estimate that $14 \%$ of workers in small businesses with 1-10 employees held no qualifications in 2003, compared with only $8 \%$ of those working in businesses employing 50 or more workers. Conversely, only $12 \%$ of workers in the smallest businesses held a degree, whereas $24 \%$ in businesses employing 50 or more people did so.

Arguments alleging insufficient employee learning and training in small businesses can be criticised. First, many training studies focus on what employers do (provide training) rather than on what employees do (learn), yet it is the latter specifically that is important for job and business performance. Employees learn in many ways other than through employer-provided training. It may be better, therefore, to describe the role of employers as the broader one of enablers of employee learning rather than just as providers of training. Second, and related, many studies have focused solely or primarily on formal training, which, though not always defined explicitly, appears to refer to planned, off-the-job activities prescribed by designated teachers; concentrating on certified training would narrow the object of study even further. Restricting the focus in this way, however, omits much, if not most, employee learning (NTSF 2000b; Fuller et al. 2003), particularly self-directed or unplanned learning arising through participation in various workplace practices (Marsick and Watkins 1987; Eraut et al. 2000; Eraut 2000). Unplanned - and even planned - on- 
the-job learning may be unrecognised by either employers or employees and, consequently, go under-reported in research studies, particularly those relying heavily on quantitative survey data allowing little opportunity to delve deeper into respondents' practices, motives for acting, and the contexts of action. Most employee knowledge and skills are uncertified (Coffield 2000) and quite possibly uncertifiable in so far as employees do not know they possess them or are unable to articulate them to others. Such omissions are particularly important in workplaces where little certified learning occurs.

In contrast, several studies emphasise the importance of informal training in small enterprises (e.g. Vickerstaff 1992; Johnson and Gubbins 1992; Abbott 1993; Curran et al. 1996; Johnson 1999; Ram et al. 2000; Perren and Grant 2001; Anderson and Boocock 2002; Hughes et al. 2002; Kitching and Blackburn 2003; SFEDI 2004; Doyle and Hughes 2004). Again, such training is not always defined explicitly; in fact, it is usually defined in terms of what it is not - formal training - but most associate it with various types of on-the-job or workplace-based practices, not involving certification. ${ }^{2}$ Others highlight the importance of interaction with coworkers and with external actors, for example, customers and suppliers, for small business owner-managers and their employees (Gibb 1997). Learning acquired through interaction with external actors can be 'cascaded' through the enterprise through subsequent interaction between co-workers (Smallbone et al. 2000; Hughes et al. 2002). Employer motives for enabling 'informal' learning and training are its 
low financial and time cost and the perceived limited quality or relevance of external training (Curran et al. 1996).

\section{THEORISING WORKPLACE LEARNING}

Human beings learn through participation in historically and socially constituted practices in the workplace, classroom and elsewhere, though the particular context will shape the process and outcomes of learning (Billett 2004). Learning is a situated and context-dependent activity. Employee learning at the workplace results from participation in the authentic goal-directed activities of particular communities of practice with the aim of developing expertise to solve routine and non-routine problems (Billett 1996). Such participation involves both planned and unplanned learning practices (Marsick and Watkins 1987; Eraut et al. 2000; Eraut 2000). Hodkinson and Hodkinson (2004) distinguish six types of learning in terms of whether learning is planned or unplanned, and whether the content is already known to others or aims at generating new or modified knowledge.

Workplace employee learning must be situated within the context of the employment relationship, one in which private sector employers' primary purpose is to produce goods and services for profitable sale as commodities (Rainbird et al. 2004). Access to, and take up of, learning opportunities must be grounded in these material realities, the divergent interests, power asymmetries and the potential for conflict between employer and employee. This highlights the political dimension of learning. Opportunities to learn might not be provided by employers or taken up by 
employees because both parties pursue goals other than enabling or undertaking learning which may limit their capacity and/or motivation to provide, or participate in, particular learning opportunities.

Workplaces can be defined as 'expansive' or 'restrictive' learning environments according to the quantity and quality of learning opportunities they enable employees to take up (Fuller and Unwin 2004). Employers play a central role in shaping learning opportunities through the design of work roles, that offer their occupants varying opportunities and incentives to learn; through enabling access to significant others at the workplace and beyond who are able to guide employee learning; and through the provision of instruments and materials from which to learn, such as the internet and equipment manuals. Employers will provide learning opportunities for employees where they anticipate the benefits of doing so - for instance, improved job performance or higher labour retention - will outweigh the likely costs, including lost working time and the risk of poaching. This raises broader issues regarding employers' product market strategies and their demand for skills: employers are unlikely to provide learning opportunities if they consider them unnecessary to achieve their business objectives (Keep and Mayhew 1999).

Employers can offer opportunities for employees to learn but employees choose whether and what to learn (Billett 2002a). Human beings possessing powers of agency are the efficient causes of action in the social world; structural pressures only have their effects mediated through human agency (Archer 1995). Employers can 
shape the conditions under which employees learn by offering incentives and threatening sanctions but cannot compel employees to learn; employers encounter a similar problem attempting the translation of labour power into actual work performance more generally. Employees may choose to learn 'inappropriate knowledge' (Billett 1996) that is either irrelevant, or even harmful, to employer objectives; these choices are shaped by broader employment relations issues which act as motivators or barriers to learning, such as the possibility of higher rewards or promotion.

\section{METHODOLOGY}

To address the research objectives, two samples of small business employers were studied in parallel: a large-scale telephone survey of 1005 business owners and a separate, face-to-face interview sample of 50 employers (Table 1). Employers in both samples were selected randomly from a Dun and Bradstreet business database on the basis of criteria relating to employment size, location and sector.

Respondents were business owners or managers, usually with responsibility for training or personnel matters. All participating businesses were legally independent, employed 2-60 workers, operated in one of six specified sector groups, and were located in one of two regions (Greater London and South Yorkshire). This yielded a quantitative dataset derived from the telephone survey, weighted to reflect the size and sector distribution of the UK business stock; and a qualitative dataset from the face-to-face interviews. The primary emphasis here is on the qualitative data as this 
best illustrates employer enablement of learning opportunities for employees and their motives for such action.

\begin{tabular}{|c|c|c|}
\hline \multicolumn{3}{|c|}{ TABLE 1} \\
\hline \multicolumn{3}{|c|}{ EMPLOYER SAMPLES BY SECTOR } \\
\hline Sectors & Telephone Survey & $\begin{array}{c}\text { Face-to-face } \\
\text { interviews }\end{array}$ \\
\hline Primary \& construction & 162 & 4 \\
\hline Manufacturing & 192 & 10 \\
\hline Distribution, hotels \& catering & 167 & 15 \\
\hline Transport \& communications & 159 & 4 \\
\hline Business \& professional services & 156 & 13 \\
\hline Other services & 169 & 4 \\
\hline Unweighted $\mathbf{N}$ & 1005 & 50 \\
\hline es were defined $u$ & ard Industrial & fication (SIC). \\
\hline
\end{tabular}

The issue of definition of 'learning and training' was handled slightly differently for the two employer samples. In the telephone survey, in order to capture as wide a range of activities as possible, employer respondents were invited to think of 'learning and training' as including: 'any activities at all through which managers and workers improve their work-related skills and knowledge. These activities may 
occur on- or off-the-job. They may occur in short bursts or be over a longer period of time. They may be linked to a qualification or not'.

In the face-to-face interviews employers were allowed to define 'learning and training' unprompted. Where respondents found these issues difficult to discuss, they were prompted using the telephone survey definition. Considerable interviewer effort was often required to encourage elaboration of workplace learning and training practices as many employers, initially, did not include them. This supports previous studies that found employers tend to adopt a narrower view of training than researchers (Campanelli et al. 1994); a similar tendency among learners to recall formal rather than informal learning episodes is noted by Eraut et al. (2000).

In the remainder of the paper, primary evidence is presented from the two employer samples to show that small business employers purposely enable learning opportunities for employees at the workplace, that these opportunities are much more diverse than many researchers have acknowledged, and that employer motives for enabling such learning opportunities cannot properly be understood without reference to the structure of the employment relationship. It should be stressed that these are employer samples; no evidence from employees is presented. In so far as small employers rely less on enabling learning opportunities outside the workplace, as previous research suggests, then workplace practices assume a greater significance. The next section provides an overview of key data from the two 
employer samples before subsequent sections explore initial learning and continuing leaning respectively.

\section{EMPLOYMENT REGULATION THROUGH EMPLOYEE LEARNING}

Small businesses, particularly micro businesses (fewer than 10 employees), do not tend to create an internal training infrastructure to support employee learning, manifested in a dedicated 'training manager', separate training budgets or written training plans for employees (e.g. Curran et al. 1996). Similar approaches are to be found in the two employer samples here. Responsibility for managing employee training often fell within the remit of managers or employees with wider duties. Though 52\% of telephone survey respondents claimed that learning and training was the responsibility of a named individual, for most of them, this responsibility was a minor element of the job; only $14 \%$ of employers claimed it was the whole or a significant part of the designated person's job. Moreover, only 5\% of respondents reported a training budget and only $4 \%$ could give a budget figure.

To what extent do small employers enable employee learning? Most employers in the telephone survey (75\%) reported the provision of workforce learning and training opportunities during the year prior to interview. But given the continuous character of learning, one has to question how useful such quantitative measures are. Similar criticisms can be made of other large-scale survey data such as the Learning and Training at Work surveys and the National Employer Skills Surveys which ask 
employers about the incidence of specific types of training, days training provided and expenditures incurred (Fuller et al. 2003: ch 3). Broader definitions of 'learning' and 'training' have to be adopted to understand how employees learn, particularly in small businesses where 'formal' and certified training are much less prevalent.

Qualitative data from the 50 face-to-face employer interviews suggest that the telephone survey data seriously understate the quantity, diversity and significance of employee learning and training activity at the workplace. Such learning activities were reported in all businesses except one, a vehicle repair business employer with 32 staff, providing a high level of external training; this may have encouraged a neglect to report workplace learning. In contrast, only 26 employers reported external training for any employees, mostly short courses of a day or less duration, whereas workplace learning and training occurred most of the time. Employers reported a wide range of employee learning practices; Eraut et al. (2000) found a similar variety of practices in a large employer context, suggesting these practices are not unique to small enterprises.

- learning-by-doing, through performance of routine working practices

- planned, on-the-job guided learning by actors at the workplace (employers, managers, co-workers and suppliers)

- unplanned interaction with actors at the workplace

- planned and unplanned learning from material artefacts, such as equipment manuals or using a computer to search the Internet 
- planned, off-the-job training courses

Of these practices, only the last could perhaps be unambiguously described as 'formal' training and, as such, likely to be captured by researchers using survey instruments. The other modes of employee learning are less structured and more likely to be described as 'informal' or possibly not to be defined as learning at all.

Employers enabled a range of learning opportunities for employees at the workplace and elsewhere, and often in combination. This was particularly the case for employers displaying a strategic orientation to employee learning and training, understood in terms of an underlying logic or strategic intent underpinning employer activity rather than as a blueprint that is subsequently translated into action. Indicators of such an approach were a written plan (or a systematic approach without a written plan) for employee learning, a dedicated training budget and explicit linking of workforce skills and learning to broader competitive strategy. Such approaches were not confined to 'knowledge-intensive' businesses or to specific sectors. For example, one removals business employer decided to raise workforce skill levels in order to compete in the more lucrative office removals niche market; another employer, selling surface protection products, adopted a formal training plan and budget and was particularly keen to raise workforce skills through workplace and external training in order to cope with intensified product market competition. These employers were more likely to plan employee learning and training, at the workplace and elsewhere. 
Nor should workplace learning and training activities, in their full variety, be judged a priori to be inferior to planned, off-the-job training courses. Indeed, an argument will be proposed that workplace practices are essential to employers and cannot be substituted by non-workplace-based learning. Employers contribute to these diverse learning processes by enabling employees to participate in particular activities. For many small employers, the 'default position' is to enable employees to learn at the workplace unless there are very specific reasons why this is infeasible or undesirable, for example, where new skills and knowledge are required that cannot be learned at the workplace. Employer perceptions of the importance of workplace learning were very evident in both samples. Telephone survey data suggested the primary benefit for employers of providing learning opportunities for employees at the workplace was their perceived 'relevance' (Table 2).

But how is 'relevance' to be interpreted? Billett (1996) suggests that the relevance of workplace learning opportunities lies in permitting access to authentic work activities and to expert others. But, more than this purely technical goal of enabling employees to acquire the skills and knowledge required for competent and safe job performance, employers have a second, political, objective: to encourage employees to exercise their knowledge and skills in a manner congruent with employer purposes. In short, enabling employee learning is intended to produce a labour force both able and willing to work in accordance with employer objectives. 


\begin{tabular}{|c|c|c|}
\hline \multicolumn{3}{|c|}{ TABLE 2} \\
\hline \multicolumn{3}{|c|}{$\begin{array}{l}\text { EMPLOYER REASONS FOR PREFERRING IN-HOUSE } \\
\text { WORKFORCE LEARNING AND TRAINING }\end{array}$} \\
\hline & $\begin{array}{l}\text { \% reporting } \\
\text { as a reason }\end{array}$ & $\begin{array}{l}\text { \% reporting as MAIN } \\
\text { reason }\end{array}$ \\
\hline Relevance & 73.1 & 55.2 \\
\hline Convenience & 66.8 & 37.5 \\
\hline Low cost & 7.1 & 3.7 \\
\hline Other reason & 1.1 & 3.4 \\
\hline No data & - & 0.2 \\
\hline Total & 100 & 100 \\
\hline Weighted N & 1005 & 273 \\
\hline Unweighted N & 1005 & 330 \\
\hline \multicolumn{3}{|c|}{$\begin{array}{l}\text { Note: data have been weighted to reflect the size distribution of UK businesses at } \\
\text { the time of interview. }\end{array}$} \\
\hline lepl & & \\
\hline
\end{tabular}

A distinction can be drawn between the knowledge and skills needed to perform a particular work role and the specific standards that constitute 'competent' job performance (as defined by the employer). Even where jobs require similar knowledge and skills, work performance standards vary between employers and, 
therefore, can only be learned in specific workplaces. By enabling employees to learn these work roles and performance standards, employers attempt to close the open-ended employment contract, by harnessing employees' subjectivities and capabilities to employers' specific objectives. These arguments will be illustrated in the next two sections using data on initial learning for new employees and on continuing learning for established employees.

\section{INITIAL LEARNING FOR NEW EMPLOYEES}

Employers use the initial period of employment to enable new staff to learn their work obligations - the specific job knowledge and skills and work performance standards - to ensure workers' efforts and creativity are channelled in 'productive' ways. These issues are relevant to employers and employees in all work organisations although the precise learning processes and outcomes will vary within and between organisations with the specific - and often changing - job and business context. Such a finding casts doubt on the oft-cited 'recruit or train' dilemma between recruiting workers already skilled and recruiting less-skilled workers and training them. Employers simply do not have the option of recruiting skilled staff and then doing nothing; even with experienced newcomers, employers must encourage them to adapt what they already know to the new organisational context or learn new knowledge and skills. 
In the 50 employer sample, all employer enablement of initial learning by new employees took place at the workplace. Employees learned through interaction with important others at the workplace, including employers, managers, co-workers and, on occasion, suppliers. This included both planned instruction or guidance, for example, being shown how to operate equipment or use software and learning arising unplanned through observation of, and/or listening to, others. For instance, discussing the creation of a marketing brochure for a client, a graphic design employer stressed the importance of guiding learning for new, especially young, recruits. The planned character of such practices belies the label 'informal'; they are deliberate, goal-directed activities (Billett 1996), though whether employees themselves would perceive them as 'training' is debateable.

You're constantly looking very closely at what they're doing. And you have to direct them more than you would the experienced designers. What we normally do if someone wants a brochure is we'll do a few ideas, a few visuals. Now with the other three [employees] $]^{3}$, by looking at what the job is and talking to the client, they'll know what's going to work and what's not going to work. Whereas a less experienced designer can come up with some ideas that just aren't practical sometimes. So you have to direct them a bit more closely, to try and stop them before they get too far down the line, before they've spent three days doing ideas that aren’t going to work. (S19: graphic designer, 6 workers) 
Employees also learn through interaction with co-workers at the workplace. Potentially, such approaches offer at least two advantages for employers. First, staff may be more knowledgeable in respect of certain tasks than employers themselves, particularly in highly skilled work roles or where the employer lacks experience. Second, employers can devote time to other activities where responsibility for enabling or supervising employee learning is delegated. One café employer, having recently bought an existing business, makes both points:

I rely on the other staff, really, to a certain extent because: (a) they have a lot of them - more experience than I have because they've been doing it a lot longer, and; (b) because I'm not always here ... Because I'm not just in one particular place, I have to rely on the other girls showing them what to do. (S5: café, 13 workers)

New recruits can learn their work obligations - work tasks and work performance standards - in unplanned activities and interactions. This means that participants in such practices, both learners and trainers, might not define them as learning or training. This has implications for researchers regarding how best to capture and measure employee learning, particularly in small enterprises where research has shown such practices to be prevalent. The following comments from a design business employer highlight the importance of co-workers as a source of learning for new recruits, the unplanned character of interaction, its importance, and the invisibility of the learning to which it gives rise. 
The main training on how we actually achieve what we do is in the office on a pretty much ad hoc basis. So a new member of staff coming into the office would be being trained without realising it ... You give the basics to the people coming in and you expect that every ten minutes for the next three months or so, they're going to have a question. And the answer will come from anybody else in the office ... There could be no other way, I don’t think, to do our mainstream training ... (S6: interior designer/architect, 12 workers, italics denote respondent emphasis)

Inculcating work obligations among new recruits might involve employer attempts to encourage employees to unlearn previously acquired work attitudes and behaviours. Again, this emphasises the specificity of work roles and performance standards; they can only be learned within the particular workplace where those roles and standards apply. Employers require new employees to learn these particular roles and standards if they are to define them as competent. Prior experience in similar work roles elsewhere can be as much a barrier to competent work performance in the new job as an aid. One employer, a publican, stresses the importance of learning specific service standards and the ambiguous relevance of previous experience.

Either me or my wife shows them what to do and how we want it to be done. Forget how they've been working anywhere else, what they're used to, how they pull a pint somewhere else. We get them to pull it how 
we want them to serve a drink ... We train them to the way how we serve behind a bar and how we want it done. (S21: public house, 14 workers)

Similarly, with regard to work performance standards in manufacturing, employers will attempt to foster a new sense of work obligation among employees and to discourage work attitudes acquired in previous employment if these are perceived to be a hindrance to competent work performance. This requires a conscious effort by employers to instill new work standards in new recruits.

... What happens is: we show them how to do the job and get the best out of that person, which may be more or less than what they've been doing before. In other words, we don't want anybody with preconceived ideas because it does limit production. We want people to do the best they can. (S1: engineering, 10 workers)

Fostering a willingness to learn on the part of new recruits is just as important an employer task as enabling the opportunity to learn. Whether employees exercise their agency to learn what employers want them to learn depends both on their ability and willingness to learn. Implicitly, employer attempts to encourage employees to learn acknowledge the political dimension of learning: that employees might not share employer objectives regarding the take-up of learning opportunities. 
I think we provide all the training that's needed. We've got enough expertise within the organisation. There's no-one outside the organisation that can give us any more ... If we get the right people, we can train them, yes. It's a matter of attitude really. (S27: construction, 10 workers)

In summary, new recruits learn their new work roles and performance standards in diverse ways, many of which would be described as 'informal' by researchers. But such a description often obscures the planned character of much of this learning. This learning is significant because employers have distinct patterns of working and specific standards of acceptable work performance; to be a 'productive' worker in a particular workplace means learning these very specific work roles and standards. Prior experience can be a necessary but never a sufficient condition for learning a new work role and employer-defined standards of acceptable work performance, as even in lower-skilled work roles, new employees will need to transfer, and adapt, prior learning to their new work environment; indeed, in some cases, prior knowledge can hinder work performance. New recruits can only learn their specific work obligations within the new workplace.

\section{CONTINUING LEARNING FOR ESTABLISHED EMPLOYEES}

Much of the initial learning undertaken by new recruits in small enterprises occurs at the workplace. But what about learning and training for more experienced staff? Is workplace learning important for them too, or do employers rely on external 
learning and training opportunities for these employees? The distinction between 'new' and 'established' employees is often difficult to draw in practice, partly because the skill levels demanded by different jobs and employee learning capabilities vary; but, conceptually, the distinction refers to those learning to become competent members upon entry to the enterprise and those existing employees looking to add to, or upgrade, their post-entry skillset.

More than three-quarters of telephone survey respondents reported that the training provided for established staff was 'mostly specific to their own businesses' (60\%) or a 'mix of specific and general training' (16\%); only $25 \%$ described their workforce training as 'mainly general training' ${ }^{4}$ Data from the face-to-face interviews reinforces the view that continuing workplace learning for established employees was important to employers.

Learning to become multi-skilled can be organised in more or less planned ways. Perhaps the most planned approach was evident in a digital media service company where workforce development was accorded a high priority by the Managing Director. Employment expansion and corresponding organisational changes had led the employer to introduce monthly 'knowledge sessions' involving 4-5 employees in different functional areas, for example, technical and marketing staff to share knowledge; routine workplace interaction was no longer perceived by the employer as sufficient to enable employees to learn adequately across departmental boundaries. Such knowledge transfer was perceived as essential if the company was to remain competitive in a turbulent market-place. The Managing Director felt there 
were few outside the business able to provide new knowledge to employees. The firm's rapidly changing knowledge base and its competitive importance, combined with business growth, led the employer to adopt a planned approach to enabling knowledge transfer and skill development, albeit one that centred primarily on workplace-based activities.

... When we started, when we were twelve people, you were listening to conversations across the room. Now, with twenty seven, you can't do that. So we have to have a more formal way of doing that training, that dispersal of knowledge. So now it's very important to grab people from different departments and put them together who wouldn’t naturally talk and chat in the same way as they did in the old days ... (L37: digital communications consultancy, 27 staff, italics used to denote respondent emphasis)

Employers frequently reported the enablement of learning opportunities for established staff through the creation of learning pathways whereby employees develop expertise by engaging in increasingly demanding tasks. Employers make work allocation decisions with a view to developing particular employees' capabilities; though, again, whether the recipients of these learning opportunities would consider them 'training' can be doubted. 
So, the training never really ceases because every repair job is a different repair job. So you're always learning. So you can say that, initially, after six months, they can cope with the simple [jobs] ... After, I should think, three to six months, they've got the basic skills on what to do and you can let them get on with it ... As they stay, we just give them more and more difficult jobs ... (S29: manufacture/repair of antique light fittings, 9 workers)

Small employers often provide training to enable employees to become multi-skilled (Hughes et al. 2002). For several reasons, smaller employers often design work roles that straddle multiple conventional job territories, for example, combining technical and sales functions within a single job. First, in small businesses, the absence of a single employee can have severe consequences; multi-skilling can solve problems arising from absence or labour turnover. Second, employers might not require a full-time employee for certain activities; creating broadly-defined jobs might justify a full-time post. By providing on-the-job, guided learning, employers (or co-workers) can enable employees to become multi-skilled, increasing the collective flexibility of the workforce.

I want them to be able to work every machine ... They need to be able work, maybe, a copy-router, an end-miller, [and] be able to hang. They need to be good all-rounders. But you don't get them. You have to bring them in, put them on one machine and take them round, move them 
round. And when they're proficient at everything, they generally bugger off! (S23: manufacturer PVC windows, 17 workers)

In addition to enabling workplace learning opportunities for established employees, employers also provided external learning and training opportunities, usually to acquire knowledge not available within the business or to meet regulatory requirements, e.g. health and safety, or for Continuing Professional Development. Data from the 50 employers suggests that external training was provided less frequently than workplace learning opportunities. Few employers attached importance to certified learning, as their primary purpose was to enable employees to acquire job-related knowledge and skills rather than to obtain qualifications. Workplace learning-by-doing and learning-by-interacting were routinely considered more important than externally-provided, and particularly certified, training.

In summary, the workplace continues to be an important site of learning for established employees after the initial period of employment. Small business employees continue to add to their skillsets through participation in a variety of workplace practices and interactions. Employers require employees to learn new knowledge and skills, and new performance standards over time. There is some evidence of employers actively attempting to construct an 'expansive' learning environment for established employees where they perceive this will generate business benefits. This is clearly influenced by the particular industry within which businesses operate and the need for employers to ensure that employees update 
knowledge and skills to meet the demands of the competitive environments within which they work. That employers require employees to continue learning and enable them to do so are widespread, although the precise form, content and outcomes of such learning will, of course, vary.

\section{CONCLUSIONS}

This study has aimed to rebalance discussion of small business employee learning and training. It attempted this, first, by shifting the focus away from training, which centres on the active role of employers as providers to employees, and towards learning, which places the learner centre stage. In this view, the role of employers is explicitly widened to being one of enabler of employee learning rather than the narrower role of training provider. The methodological approach adopted encouraged employers to consider a wider range of practices and interactions as learning opportunities than have been considered by many, particularly quantitative, researchers. But it was only in the face-to-face interviews that the diversity and significance of learning practices became clear. Large-scale survey research instruments may be incapable of detecting the quantity and quality of learning and training experiences reported here: employers and employees might simply have not reported them. Such survey findings have given rise to the misconception that small employers do not provide sufficient training, nor their employees engage in sufficient learning. Narrower definitions of 'training' centring on certified learning paint an even more one-sided picture. Employees learn in many ways, some of 
which employers and/or employees may be unaware, yet which are important to job and business performance.

Second, in contrast to studies which treat workplace learning and training as 'informal' and, by implication, inferior, it is argued that the 'default position' for most small employers is to enable learning opportunities at the workplace for both new recruits and established staff unless there are strong reasons to do otherwise. Employer motives for enabling workplace learning opportunities extend beyond the usual arguments of low financial and time cost to the crucial issue of relevance, understood in terms of encouraging employees to learn knowledge, skills and attitudes congruent with employer objectives. Employers often feel they are able to exert greater influence over the content and process of employee learning where this takes place at the workplace. The incidence and importance of externally-provided is not denied; but it is recognised as just one source of employee learning. Employees learn primarily through participation in a wide range of workplace practices and interactions.

Third, previous studies have understated or ignored the political dimension of workplace learning. Employee learning and employer enablement of learning opportunities must be understood within the broader context of the employment relationship. It cannot be assumed that employers and employees share the same interests in providing or taking up learning opportunities. Employers have an interest in enabling employees to learn the specific work roles and performance standards 
they perceive as relevant to becoming competent workers within their businesses. Employers have greater power than employees to design jobs and structure workplace relationships to enable or restrict learning opportunities for employees. Consequently, employers exert a strong, though not determinate, influence over how and what employees learn. This inevitably shapes employees' attitudes to, and experiences of, learning. Ultimately, employers cannot compel employees to learn 'appropriate' knowledge; employees can choose to take up learning opportunities or not and this raises broader employment relations issues which act as motivators or barriers to learning. Further research, drawing directly on data from employees themselves could better illuminate their perceptions of, attitudes towards, and motivations to take up learning opportunities.

\section{ACKNOWLEDGEMENTS}

The author would like to acknowledge the Department for Education and Employment (now the Department for Education and Skills) and the Small Business Council for funding the research upon which this paper is based.

\section{NOTES}

${ }^{1}$ I am grateful to Sarah Poulton (IiP UK) for data on recognitions by size of organisation (email communication 5/9/05). Percentage calculations made using data 
on business size for 2004 drawn from the Small Business Service website (www.sbs.gov.uk).

${ }^{2}$ Some avoid using the formal/informal distinction in relation to learning and training. Billett (2002b) suggests that describing workplace learning practices as informal fails to recognise their intentionality, authenticity and significance, and privileges, explicitly or implicitly, learning activities occurring in other settings, for example, educational organisations. Colley et al. (2003) argue that all learning activities involve both formal and informal aspects - location/setting, purpose, content and process - and that, therefore, reference to formal and informal training as distinct types should be avoided.

${ }^{3}$ Bracketed words and phrases have been added by the author to retain the sense of verbatim quotations.

${ }^{4}$ Categories do not sum to $100 \%$ due to rounding. 


\section{REFERENCES}

Abbott, B. 1993. 'Training Strategies in Small Service Sector Firms: Employer and Employee Perspectives', Human Resource Management Journal, Vol. 4, no. 2, 4087.

Anderson, V. and Boocock, J. 2002. 'Small Firms and Internationalisation: Learning to Manage and Managing to Learn', Human Resource Management Journal, Vol. 12, no. 3, 5-24.

Archer, M. 1995. Realist Social Theory: The Morphogenetic Approach, Cambridge University Press, Cambridge.

Billett, S. 1996. 'Towards a Model of Workplace Learning: the Learning Curriculum', Studies in Continuing Education, Vol. 18, no. 1, 43-58.

Billett, S. 2002a. 'Workplace Pedagogic Practices: Co-Participation and Learning', British Journal of Educational Studies, Vol. 50, no. 4, 457-481.

Billett, S. 2002b. 'Critiquing Workplace Discourses: Participation and Continuity at Work', Studies in the Education of Adults, Vol. 34, no. 1, 56-67. 
Billett, S. 2004. 'Learning Through Work: Workplace Participatory Practices', in H. Rainbird, A. Fuller, and A. Munro (eds). Workplace Learning in Context, Routledge, London.

Campanelli, P. and Channele, J. with McCauley, L., Renouf, A. and Thomas, R. 1994. Training: An Explanation of the Word and Concept with an Analysis of the Implications for Survey Design, Employment Department, Research Series No 30, London.

Coffield, F. 2000. 'The Structure Below the Surface: Reassessing the Significance of Informal Learning', in F. Coffield, (ed). The Necessity of Informal Learning, Policy Press, Bristol.

Colley, H., Hodkinson, P. and Malcolm, J. 2003. Informality and Formality in Learning, a report for the Learning and Skills Research Centre www.lsda.org.uk/files/pdf/1492.pdf

Cosh, A., Hughes, A, with Bullock, A. and Potton, M. 2003. The Relationship Between Training and Business Performance, DfES Research Report RR454, DfES.

Curran, J., Blackburn, R. A., Kitching, J. and North, J. 1996. Establishing Small Firms' Training Practices, Needs, Difficulties and Use of Industry Training Organisations, Research Studies RS17, DfEE/HMSO, London. 
Department for Education and Skills (DfES) 2003. $21^{\text {st }}$ Century Skills: Realising Our Potential, Individuals, Employers, Nation, cm 5810, Stationery Office, London.

Department for Education and Skills (DfES) 2005. Skills: Getting on in Business, Getting on at Work, cm 6483, Stationery Office, London.

Doyle, L. and Hughes, M. 2004. Learning Without Lessons: Supporting Learning in Small Businesses, Learning and Skills Development Agency, http://www.lsda.org.uk/files/pdf/1685.pdf

Eraut, M. 2000. 'Non-formal Learning, Implicit Learning and Tacit Knowledge in Professional Work', in F. Coffield, (ed). The Necessity of Informal Learning, Policy Press, Bristol.

Eraut, M., Alderton, J., Cole, G. and Senker, P. 2000. 'Development of Knowledge and Skills at Work', in F. Coffield, (ed). Differing Visions of a Learning Society: Volume 1, Policy Press, Bristol.

Fitzgerald, R., Taylor, R. and LaValle, I. 2003. National Adult Learning Survey (NALS) 2002, DfES, Research Report 415, London.

Freel, M. 2005. 'Patterns of Innovation and Skills in Small Firms', Technovation, Vol. 25, no. 2, 123-134. 
Fuller, A., Ashton, D., Felstead, A., Unwin, L., Walters, S. and Quinn, M. 2003. The Impact of Informal Learning at Work on Business Productivity, DTI, London.

Fuller, A. and Unwin, L. 2004. 'Expansive Learning Environments: Integrating Organisational and Personal Development', in H. Rainbird, A. Fuller, and A. Munro (eds). Workplace Learning in Context, Routledge, London.

Gibb, A. 1997. 'Small Firms' Training and Competitiveness: Building Upon the Small Business as a Learning Organisation', International Small Business Journal, Vol. 15, no. 3, 13-29.

HM Treasury 2002. Developing Workforce Skills: Piloting a New Approach, HM Treasury, London.

HM Treasury 2004. Skills in the Global Economy http://www.hm-treasury.gov.uk/media/8F5/94/pbr04skills_410.pdf

Hodkinson, P. and Hodkinson, H. 2004. 'The Complexities of Workplace Learning: Problems and Dangers in Trying to Measure Attainment', in H. Rainbird, A. Fuller, and A. Munro (eds). Workplace Learning in Context, Routledge, London. 
Hughes, M., Keddie, V., Webb, P. and Corney, M. 2002. Working Towards Skills: Perspectives on Workforce Development in SMEs, Learning and Skills Development Agency, http://www.lsda.org.uk/files/PDF/1307R.pdf

Johnson, S. 1999. Skills Issues for Small and Medium sized Enterprises, Skills Task Force Research Paper 13, Middlesex University Business School, London.

Johnson, S. and Gubbins, A. 1992. 'Training in Small and Medium-Sized Enterprises: Lessons from North Yorkshire’, in Caley, K., Chell, E., Chittenden, F. and Mason, C. (eds) Small Enterprise Development: Policy and Practice in Action, Paul Chapman, London.

Keep, E. and Mayhew, K. 1999. 'The Assessment: Knowledge, Skills and Competitiveness', Oxford Review of Economic Policy, 15, 1, 1-15.

Kitching and Blackburn (2002) The Nature of Training and Motivation to Train, DfES Research Report 30, Nottingham.

Kitching, J. and Blackburn, R. (2003) Measuring Training in Small Firms, Small Business Council, London. 
Kitson, M. and Wilkinson, F. 2003. 'Labour Mobility, Training and Labour Force Flexibility', in A. Cosh, and A. Hughes (eds). Enterprise Challenged, ESRC Centre for Business Research, Cambridge University.

Learning and Skills Council (LSC) 2005. National Employer Skills Survey 2004: Main Report, http://readingroom.lsc.gov.uk/lsc/2005/research/commissioned/national-employersskills-survey-main-report-2004.pdf

Leitch Review of Skills (2005) Skills in the UK: the Long-term Challenge, Interim Report, http://www.hmtreasury.gov.uk/independent_reviews/leitch_review/review_leitch_index.cfm

Marsick, V. and Watkins, K. 1987. 'Approaches to Studying Learning in the Workplace', in V. Marsick (ed). Learning in the Workplace, Croom Helm, London

Matlay, H. 2004. 'Contemporary Training Initiatives in Britain: a Small Business Perspective', Journal of Small Business and Enterprise Development, Vol. 11, no. 4, 504-513.

National Skills Task Force (NTSF) 2000a. Skills for All: Proposals for a National Skills Agenda, Final Report of the National Skills Task Force, London. 
National Skills Task Force (NTSF) 2000b. Tackling the Adult Skills Gap: Upskilling Adults and the Role of Workplace Learning, Third Report of the National Skills Task Force, London.

Perren, L. and Grant, P. 2001. Management and Leadership in UK SMEs: Witness testimonies from the World of Entrepreneurs and SME Managers, Council for Excellence in Management and Leadership, London.

Rainbird, H., Munro, A. and Holly, L. 2004. 'The Employment Relationship and Workplace Learning', in H. Rainbird, A. Fuller, and A. Munro (eds). Workplace Learning in Context, Routledge, London.

Ram, M., Sanghera, B., Abbas, T. and Barlow, G. 2000. 'Training and Ethnic Minority Firms: the Case of the Independent Restaurant Sector', Education and Training, Vol. 42, no. 4/5, 334-341.

Smallbone, D., Supri, S. and Baldock, R. 2000. 'The Implications of New Technology for the Skill and Training Needs of Small- and Medium-sized Printing Firms’, Education \& Training, Vol. 42, nos. 4/5, 299-307.

Small Firms Enterprise Development Initiative (SFEDI) 2004. Small Businesses: Skills Assessment $\quad 2004, \quad$ SFEDI, $\quad$ Sheffield http://www.sfedi.co.uk/ourWork/ourWork.htm 
Smith, A., Boocock, G. Loan-Clarke, J. and Whittaker, J. 2002. 'IiP and SMEs: Awareness, Benefits and Barriers', Personnel Review, Vol. 31, no. 1, 62-85.

Vickerstaff, S. 1992. 'The Training Needs of Small Firms', Human Resource Management Journal, Vol. 2, no. 3, 1-15.

Westhead, P. 1998. 'Factors Associated with the Provision of Job-Related Formal Training by Employers', International Journal of Entrepreneurial Behaviour \& Research, Vol. 4, no. 3, 187-216.

Westhead, P. and Storey, D. 1997. Training Provision and the Development of Small and Medium-Sized Enterprises, DfEE Research Report No. 26, DfEE/HMSO, London. 